\title{
THE DYNAMICS OF MOBILITY IN THE LIGHT OF THE ASSESSMENT OF MANDATORY TESTS, INTRODUCED IN THE NATIONAL SYSTEM OF EVALUATION, IN STUDENTS IN PRIMARY AND SECONDARY EDUCATIONAL STAGES
}

\author{
Georgian BĂDICU* \\ orcid.org/0000-0003-4100-8765 \\ ${ }^{1}$ Transilvania University of Brasov, \\ Faculty of Physical Education and Mountain Sports, Romania \\ georgian.badicu@unitbv.ro
}

\begin{abstract}
:
Objectives: The objective of this article is a comparative analysis of the dynamics of mobility in the light of the assessment of certain motor skills tests introduced in the primary and secondary educational system.
\end{abstract}

Methods: This research was conducted on October 2015 - April 2016, on a sample of 190 students, with ages between 7 and 15. The students undergoing this research were tested on eight motor aptitude tests in the National Assessment System of Physical Education and Sports (four tests for the primary education and four for the secondary education) and the results were compared depending on gender and stage of education.

Results: On the $5 \times 5 \mathrm{~m} / 5 \times 10 \mathrm{~m}$ "shuttle" test, the dynamics of mobility was on a downward trend, both in girls and boys; on the long run test, on both genders, the dynamics of motion was on an upward trend whereas in students from the secondary education level the dynamics of mobility showed small variations; on the standing long jump test, on girls, the dynamics is on an upward trend, with very small variations, and in the secondary educational cycle, the dynamics of results shows a continuous increase, just as in boys, in both cycles of education; on the last test of aerobatic gymnastics, the dynamics of the results obtained by both girls and boys shows variations, within both cycles of education.

Conclusions:The dynamics of mobility in students has shown low values in the case of the $5 \times 5 \mathrm{~m}$ shuttle test, in both educational cycles (both in boys and girls). The best results were achieved on the long run test, respectively on the endurance run and standing long jump. 
Keywords: motor ability, dynamics, students, assessment, educational cycle

\section{INTRODUCTION}

The concepts of psychomotor ability, psychomotor development and psychomotor deficiency are often defined in a different, even contradictory manner, depending on different schools and authors.

Nowadays, in our society, motor activity not only continues to be significantly important in the process of cognitive development and shaping of personality, but also represents a direct stimulus - almost exclusive - for one of the fundamental biological functions of every living being, of humans in particular (general mobility) ${ }^{2,3}$.

The general mobility is the function that enables a coordinated movement of several body parts or of the entire body, with or without visual control,that combines actions of locomotion, of orientation change, of generating a force ${ }^{1}$.

As far as the motor particularities of children in primary school are concerned, the author Balint ${ }^{4}$ states that these can be studied in the light of the level of instilling basic motor abilities and locomotor skills in children.

The motor ability in this stage is very strong, the capacity of motor learning is remarkable but the possibility of entrenching the newly acquired moves is low. Therefore, only a systematic repetition integrates and consolidates the new move in the child's motor ensemble. The fundamental motor skills are subject to a process of consolidation - improvement. At the beginning of the 7 years period, the child has positioning difficulties in relation to the ball trajectory. At the age of $9-11$, the positioning for the ball is steadier and is characterized by maintaining a vertical postural stability.

Puberty represents an optimal period for learning most of the motor skills that are sports specific, as well as for the development of motor abilities such as speed, endurance, bodily coordination. In addition to the improvement of basic motor skills, acquired in previous stages, the initiation in undergoing some sports activities and tests through acquiring technical and tactical elements specific to these activities is also one of the important objectives of this stage ${ }^{5}$.

The latter must be accompanied by an increased capacity of applying the motor skills in various circumstances and during leisure time ${ }^{6}$.

Also, during puberty (age of $10-14$ ), mobility is characterized by a steep somatic development, especially between the age of $12-14$. This age is characterized by an imbalance between the sizes of different body parts and between morphology and growth. The articular mobility shows relatively low values both in girls and boys ${ }^{6}$.

The assessment of students' aptitudes in physical education is done 
depending on the objectives presented in the curriculum. This assessment aims at aspects such as physical and theoretical training, as well as the development of the child's intellect and of physical and functional skills etc. The assessment of the students' aptitudes is part of the educational process, which involves verification, evaluation and awarding of grades.

The National Education System of Assessment in Physical Education and Sports (S.N.E.E.F.S.) seeks to assess the main aptitudes and competencies foreseen in the curriculum ${ }^{8}$.

The evaluation criteria included in S.N.E.E.F.S. aim at achieving the framework objectives and the final standards of performance specific for each educational cycle, as well as the competencies established for each class, in the field of motor capacity, that is related to the practicing of sports branches provided for in the curriculum ${ }^{8}$.

The assessment system is related to the current provisions of the education plan and of the content of curricula, and it is applicable in all schools, regardless of available conditions; the system is meant only for classes that have physical education included in their commun curriculum ${ }^{8}$.

Within the primary education cycle, the assessment is done through scores and in secondary education through grades. In primary education, the semestrial assessment will encompass at least three scores in each semester, whereas in secondary education, it is recommended that the semestrial assessment contain at least three grades (for the fifth, sixth and seventh grade) and two grades, for the eight grade, for each semester of the academic year.

The purpose of this research is to show the dynamics of mobility in the light of the assessment of mandatory tests provided for in S.N.E.E.F.S., for students in primary and secondary education.

\section{Material and methods}

The research was conducted on October 2015 - April 2016 on a sample of 190 students, out of whom 90 were boys and 100 girls, aged between 7 and 15. The subjects of this study were students from "Andrei Mureșanu" High School - Braşov county, in primary and secondary education cycle. The students underwent eight mandatory tests included in the National System of Assessment in Physical Education and Sports, as follows: for primary education - test one - $5 \times 5 \mathrm{~m}$ shuttle; test 2 - long run; test 3 - standing long jump and test 4 - aerobatic gymnastics ; for secondary education - test $1-5 \times 10 \mathrm{~m}$ shuttle; test 2 - endurance run $(500-800 \mathrm{~m}$ girls; $800-1000 \mathrm{~m}$ - boys); test 3 - standing long jump and test 4 - aerobatic gymnastics.

For this assessment, there were chosen classes in each age category, one class per age category (I - VIII classes) for each education cycle (primary - secondary). We mention that, on some tests of motor skills, the SNEEFS scores were converted into grades. 
After the students underwent the motor skills tests, a comparative analysis of their results dynamics was completed, depending on gender, for both educational cycles.

\section{Results and discussions}

\subsection{Interpretation of the assessment results}

3.1.1. Comparative results from the $5 \times 5 \mathrm{~m}$ and $5 \times 10 \mathrm{~m}$ shuttle test-girls and boys (primary and secondary education)

From the recorded data we notice that in both cycles of education the dynamics of the results obtained by girls is on an downward trend (Fig. 1), the arithmetic average of the results obtained in primary education being: in 1st grade, 6"91, in second grade, 6"80, in third grade, 6"72 and in forth grade, 6"66. In secondary education, in fifth and sixth grade, the results obtained on this test are equal, $22^{\prime \prime} 73$, in seventh grade the value is $22 " 12$ and in eight grade 21 "66 (Fig. 1).

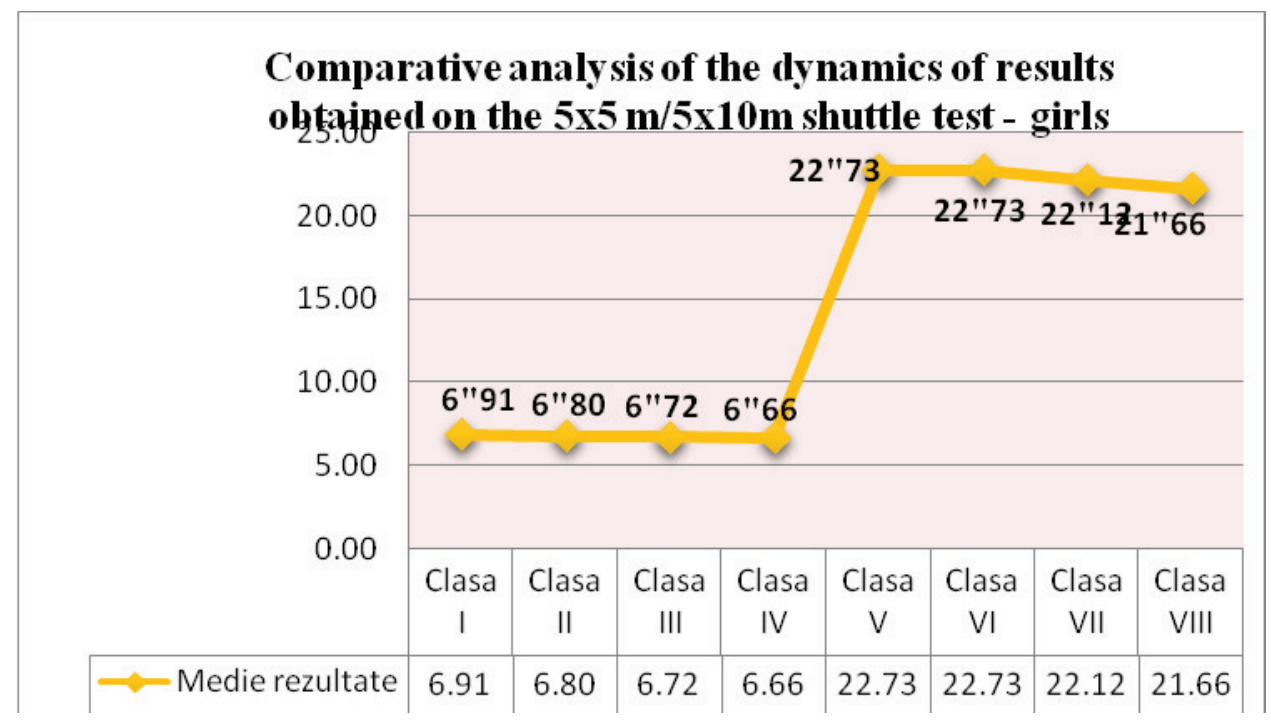

Fig. 1. The dynamics of results obtained on the $5 \times 5 \mathrm{~m} / 5 \times 10 \mathrm{~m}$ shuttle test girls

As far as boys are concerned, the dynamics of results is on the same downward trend (Fig. 2), the arithmetic averages of the results obtained in primary education being: in first grade, 6"54, in second grade, 6"47, in third grade, 6"31 and in forth grade, 6"26. In secondary education, the values are the following: in fifth grade, $21 " 98$, in sixth grade, $21 " 59$, in seventh grade, 21 "08, and in eight grade, $20 " 10$ (Fig. 2). 


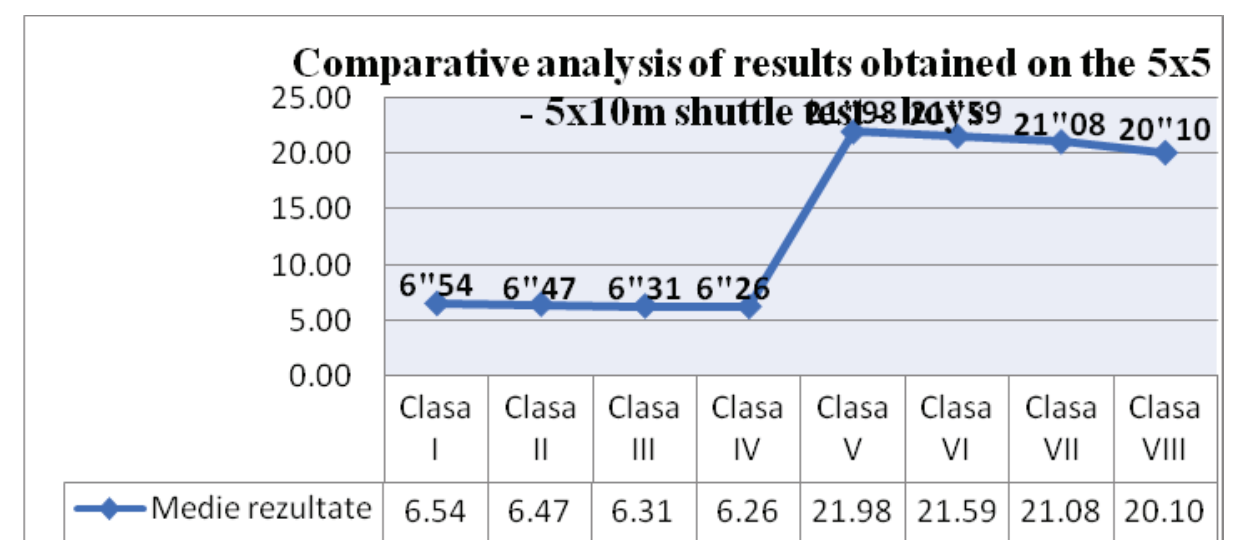

Fig. 2. The dynamics of results obtained on the $5 \times 5 \mathrm{~m} / 5 \times 10 \mathrm{~m}$ shuttle test boys

3.1.2. Comparative results achieved on the long run test (primary education) and the endurance run test (500-800m - girls; 800-1000m-boys)

In primary education, the dynamics of results achieved by girls on the long run test is on an upward trend, whereas in secondary education, the dynamics of results on the endurance run shows small variations (Fig. 3).

The arithmetic averages of results whitin primary education were: in first grade, 1'38", in second grade, 1'46", in third grade, 2'17" and in forth grade, 2'34". In secondary education, we have the following results: in fifth grade, 3'43", in sixth grade, 3'13" (for the $500 \mathrm{~m}$ run), in seventh grade, 4'47", and in eight grade, 4'37" (for the $800 \mathrm{~m}$ run) (Fig. 3).

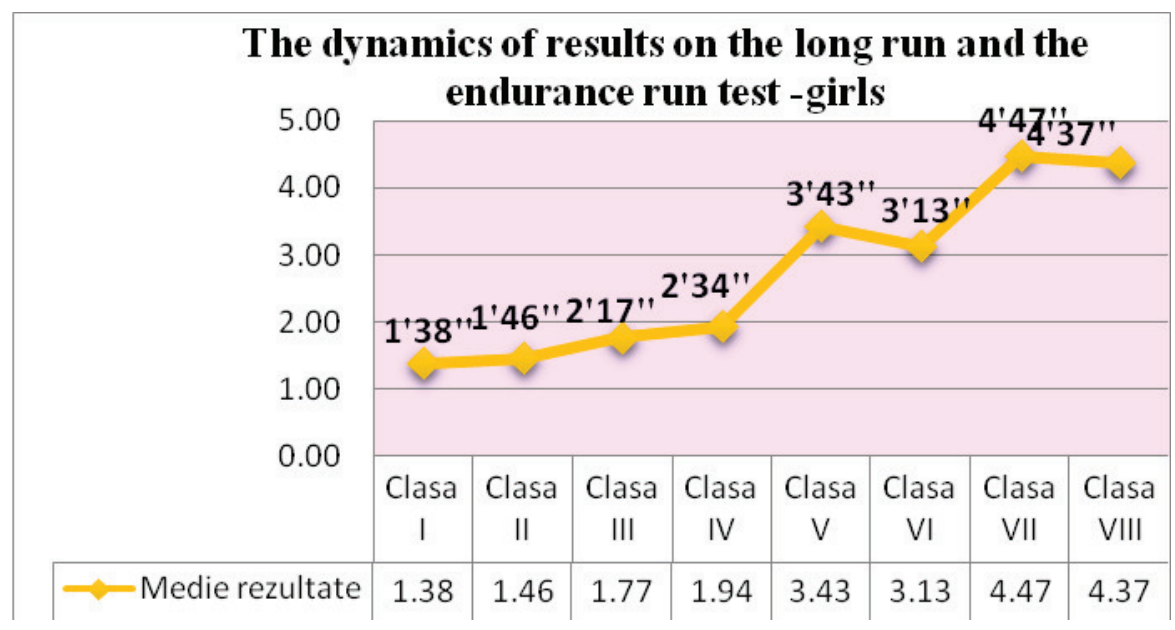

Fig. 3. The dynamics of results on the long run and the endurance run test girls 
In primary education, the dynamics of results achieved by boys in the long run test is on an upward trend, and in secondary education, the dynamics of results on the endurance run test shows small variations, same as in girls. (Fig. 4).

The arithmetic averages of results obtained in primary education were: in first grade, 1'42", in second grade, 2'26", in third grade, 2'09" and in forth grade, 2'35". In secondary education, the achieved results were: in fifth grade, 3'79", in sixth grade, 3'51" (for the $800 \mathrm{~m}$ run), in seventh grade, 4'53", and in eight grade, 4'45" (for the $1000 \mathrm{~m}$ run) (Fig. 4).

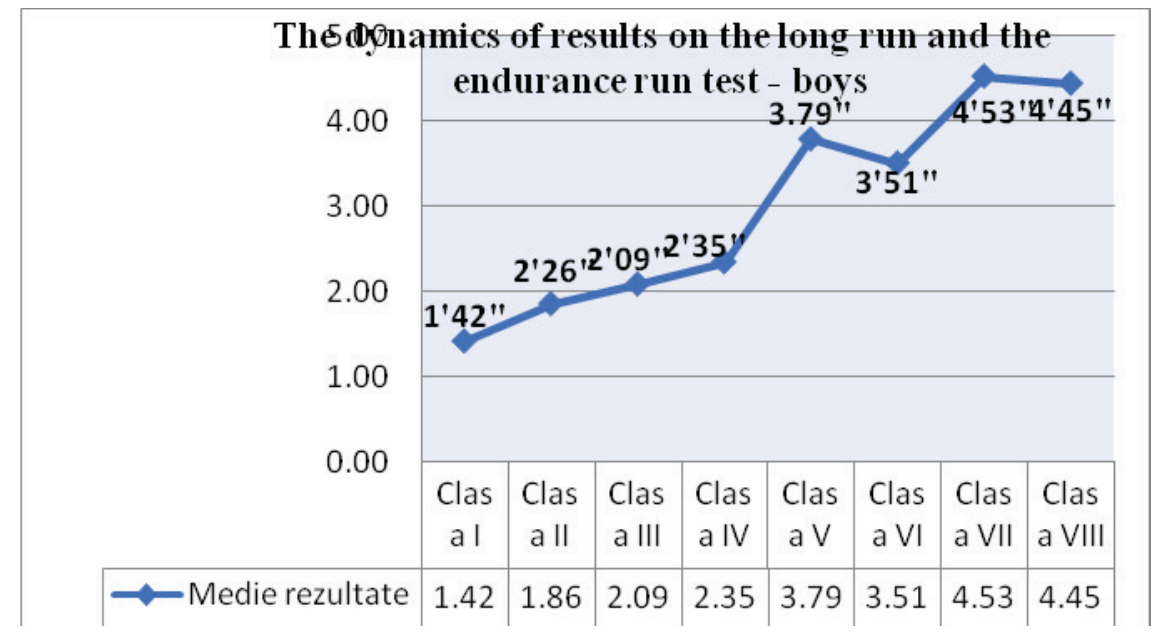

Fig. 4. The dynamics of results on the long run and the endurance run test- boys

3.1.3. Comparative results achieved on the standing long jump test-girls and boys (primary and secondary education).

In primary education, the dynamics of the results obtained by girls on the standing long jump test is on an upward trend, with very small variations, and in secondary education the dynamics of results shows a continuous growth. (Fig. 5).

The arithmetic averages of results in primary education were: in first grade, $1 \mathrm{~m} 07 \mathrm{~cm} "$, in second grade, $1 \mathrm{~m} 13 \mathrm{~cm}$, in third grade, $1 \mathrm{~m} 12 \mathrm{~cm}$ and in forth grade, $1 \mathrm{~m} 19 \mathrm{~cm}$. In secondary education, we have the follwing results: in fifth grade, $1 \mathrm{~m} 24 \mathrm{~cm}$, in sixth and seventh grade -the values are equal, $1 \mathrm{~m} 37 \mathrm{~cm}$, and in eight grade, $1 \mathrm{~m} 39 \mathrm{~cm}$ (Fig. 5). 


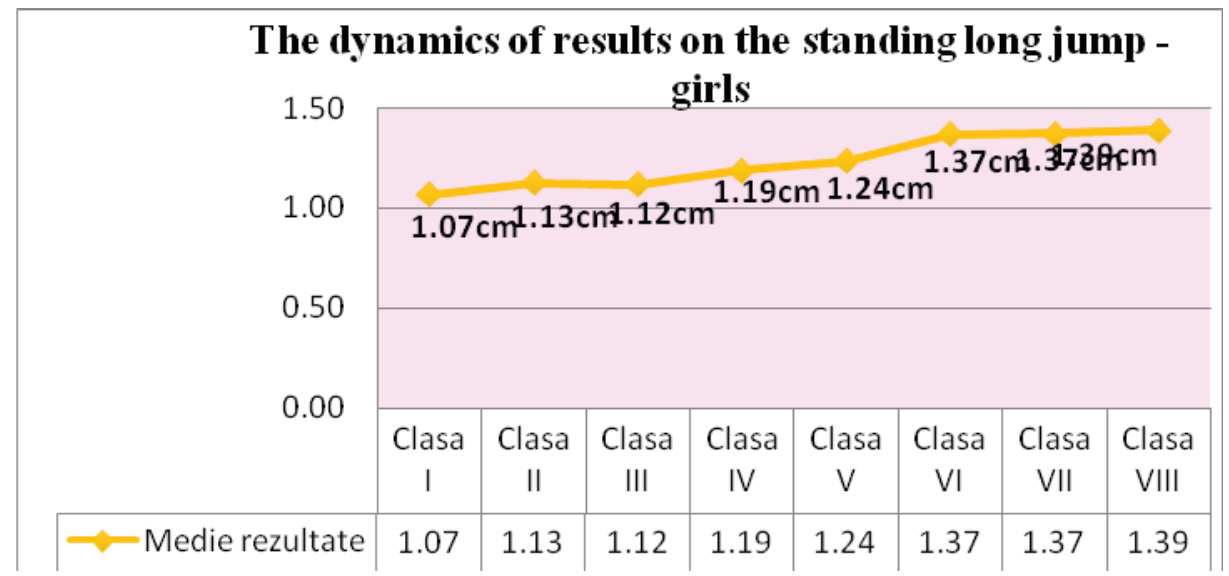

Fig. 5. The dynamics of results on the standing long jump test - girls

As far as boys are concerned, in primary and secondary education, the dynamics of results is continuously growing (Fig. 6).

The arithmetic averages of results obtained in primary education were: in first grade, $1 \mathrm{~m} 12 \mathrm{~cm}$, in second grade, $1 \mathrm{~m} 15 \mathrm{~cm}$, in third grade, $1 \mathrm{~m} 20 \mathrm{~cm}$ and in forth grade, $1 \mathrm{~m} 24 \mathrm{~cm}$. In secondary education, we have the following results: in fifth grade, $1 \mathrm{~m} 48 \mathrm{~cm}$, in sixth grade, $1 \mathrm{~m} 53 \mathrm{~cm}$, in seventh grade, $1 \mathrm{~m} 58 \mathrm{~cm}$, and in eight grade, $1 \mathrm{~m} 67 \mathrm{~cm}$ (Fig. 6).

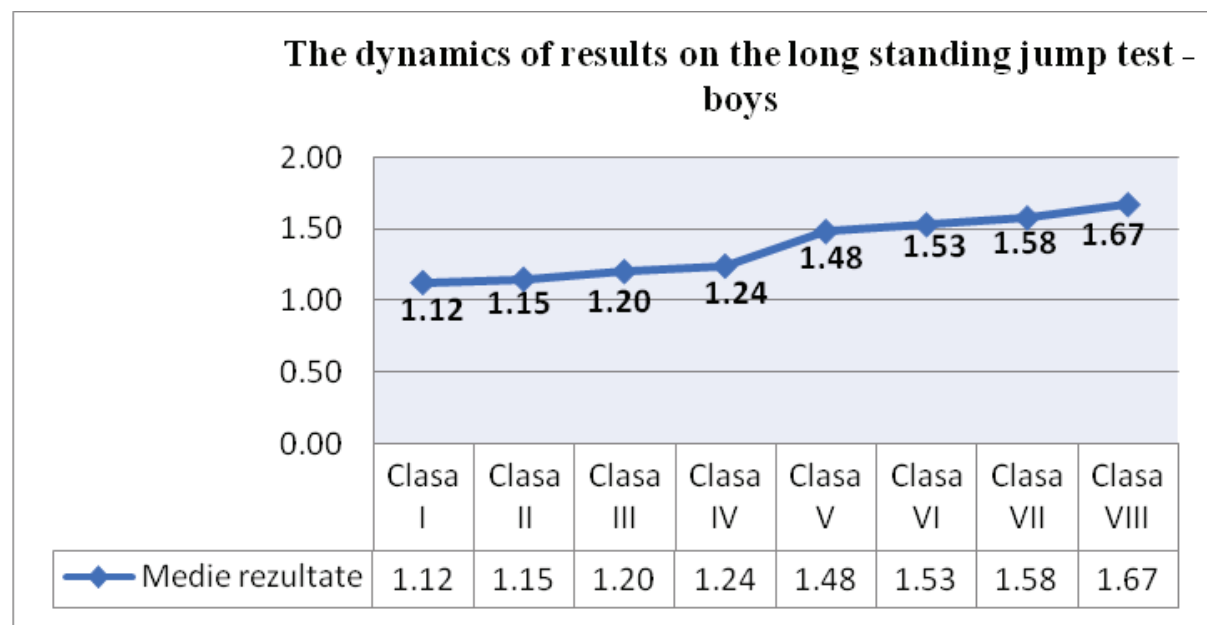

Fig. 6. The dynamics of results on the long standing jump test - boys 
3.1.4. Comparative results achieved on the aerobatic gymnastics test (isolated aerobatic elements) - girls and boys (primary and secondary education).

The dynamics of results obtained by both girls and boys in gymanstics shows variations (oscilations), in both educational cycles (Fig. 7; 8).

The arithmetic averages of results achieved by girls in primary education were: in first grade, 7.44, in second grade, 7.39, in third grade, 7.31 and in forth grade, 7.41. In secondary education, the results are as follows: in fifth grade, 7.64, in sixth grade, 7.67, in seventh grade, 7.32, and in eight grade, 7.58 (Fig. 7).

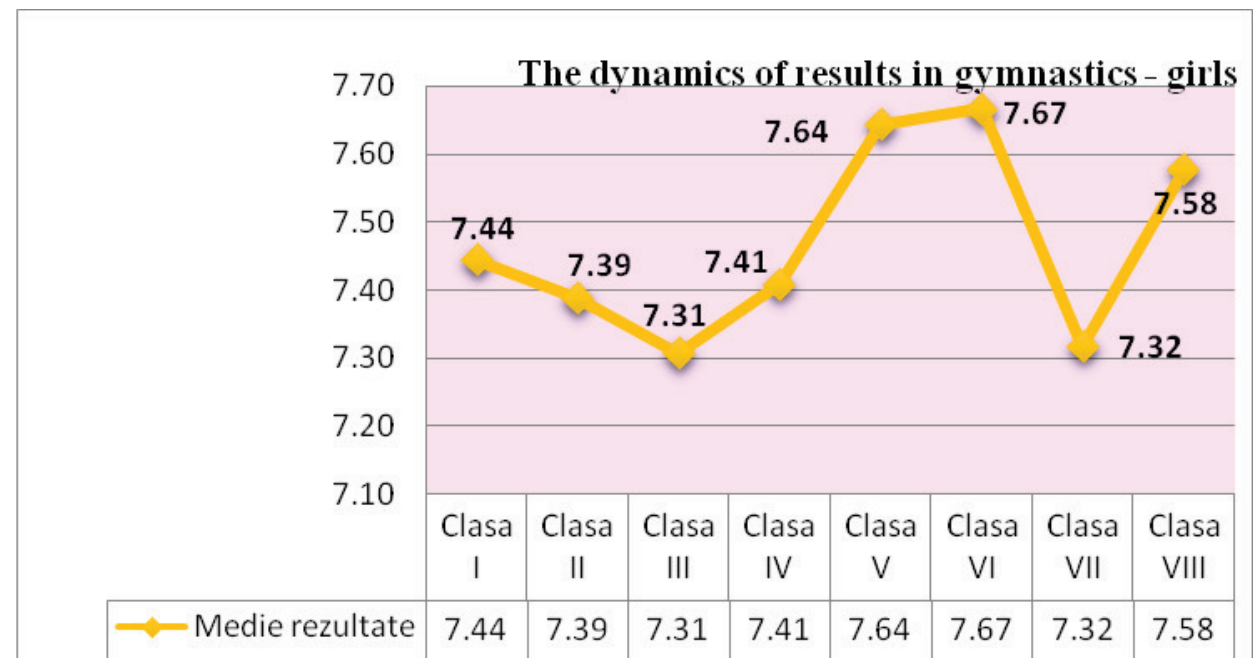

Fig. 7. The dynamics of results in gymnasctics - girls

The arithmetic averages of results acheived by boys in primary education were: in first grade, 7.75, in second grade, 7.75, in third grade, 7.67 and in forth grade, 7.78. In secondary education, we present the following values: in fifth grade, 7.91, in sixth grade, 7.70, in seventh grade, 7.67, and in eight grade, 8.00 (Fig. 8). 


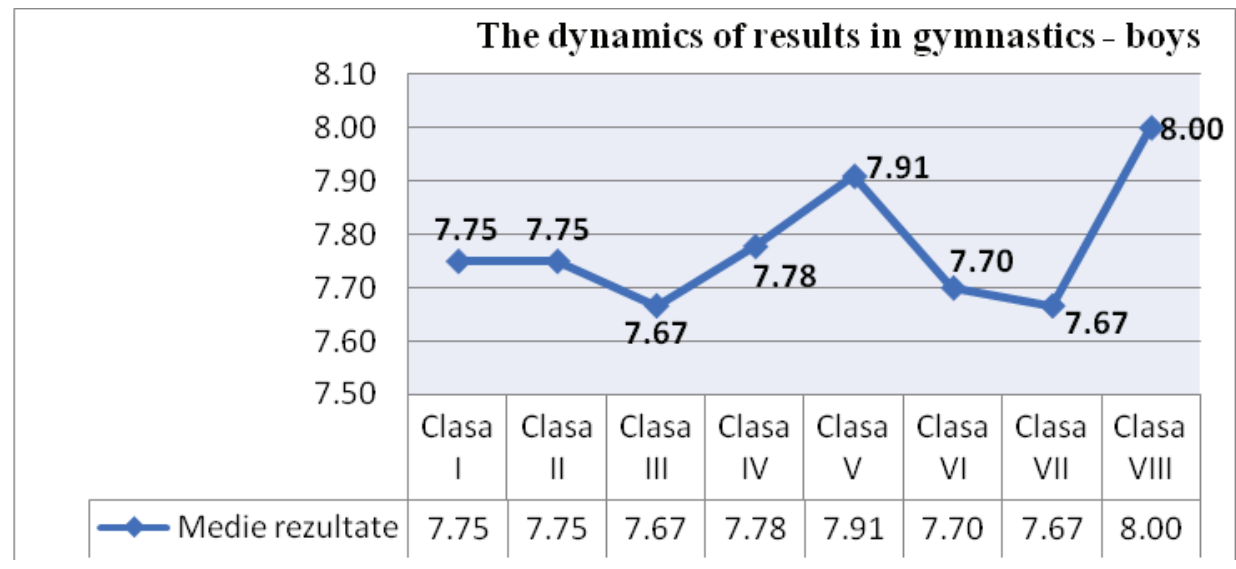

Fig. 8. The dynamics of results in gymnastics - boys

\section{Conclusions}

The study of mobility in published literature is performed on a structural and functional basis and it looks at mobility as a necessity that makes the system viable, in continuous development and adjustable $e^{7}$

The results of our research have shown that the dynamics of students' mobility had the lowest values on the $5 \times 5 \mathrm{~m}$, respectively, $5 \times 10 \mathrm{~m}$ shuttle test, for both educational cycles (both in boys and in girls). However, the best results were obtained on the long run test, the endurance run and on the standing long jump. The highest variations of mobility were achieved on the aerobatic gymnastics test, for both educational cycles.

\section{References}

Frédérique W.K. - (Psiho) MOTRICITATE - Sprijin, prevenţie şi compensare.Editura Asociaţiei de Ştiinţe Cognitive din România, ClujNapoca, 2014, p.10.

Balint L. - Teoria educaţiei fizice şi sportului. Editura Universităţii Transilvania din Braşov, Braşov, 2003, p.13.

Matveev L.P. şi colab. - Teoria şi metodica educaţiei fizice. Editura SportTurism, Bucureşti, 1980.

Balint L. - Practica şi metodica activităţilor motrice pe grupe de vârstă curs de uz intern, Braşov, 2009.

http://www.creeaza.com/didactica/didacticapedagogie/MOTRICITATEA719.php, accessed on the 20th of June 2017. http://www.rasfoiesc.com/sanatate/medicina/MOTRICITATEA-IN-ETAPAPUBERTAR78.php, accessed on the 20th of June 2017. 
Journal Plus Education, ISSN: 1842-077X, E-ISSN (online) 2068-1151 Vol XVIII (2017), No. nov. pp. 112-121

https://mariananu.wordpress.com/psihologie/activitatea-motrica-sipersonalitatea/mecanismele-autocontrolului-in-efectuareaactiunii/biomotrie/teoria-activitatilor-motrice/, accessed on the 21 st of June 2017.

http://cyd.ro/istoric-al-sistemelor-de-evaluare-aplicate-in-romania/, accessed on the 22nd of June 2017. 